\title{
HEAVY METAL ANALYSIS IN RED OAK (QUERCUS RUBRA) POPULATIONS FROM A MINING REGION IN NORTHERN ONTARIO (CANADA): EFFECT OF SOIL LIMING AND ANALYSIS OF GENETIC VARIATION
}

\author{
${ }^{1}$ Anh Tran, ${ }^{1}$ K.K. Nkongolo, ${ }^{1}$ M. Mehes-Smith, \\ ${ }^{1}$ R. Narendrula, ${ }^{2,3}$ G. Spiers and ${ }^{1} P$. Beckett \\ ${ }^{1}$ Department of Biology, \\ ${ }^{2}$ Department of Chemistry and Biochemistry, \\ ${ }^{3}$ Elliot Lake Research Field Station, \\ Laurentian University, 935 Ramsey Lake Road, Sudbury, Ontario, P3E-2C6, Canada
}

Received 2014-04-22; Revised 2014-04-25; Accepted 2014-06-25

\begin{abstract}
Understanding the dynamic of metals in soil and plants and population diversity in Northern Ontario is essential in determining progress toward ecosystem sustainability in reclaimed sites. The objectives of the present study were to assess the levels of metal content in soils and their accumulation in red oak plants from limed and unlimed sites. Genetic variation in red oak populations from the Northern Ontario region was also analyzed. The levels of soil acidity was lower in limed areas compared to un limed sites, an indication of the prolonged beneficial effect of liming 20 to 30 years ago on soil toxicity. The levels of total metals were very high for most elements, but the proportion of metals that were bio available and readily available to plants was very small. The enrichment factors were 16.78, 4.98 and 2.94 for total arsenic, copper and nickel, respectively. The Translocation Factor (TF) values for available metals from soil to branches were high. There was more metal accumulation in leaves compared to branches. The degrees of genetic variability in red oak populations from limed and unlimed areas were compared using ISSR markers. The levels of polymorphic loci were moderate to high ranging from 44 to $65 \%$. There were no significant differences in polymorphisms between areas that were limed and unlimed. Overall the red oak populations in stressed areas in Northern Ontario are sustainable.
\end{abstract}

Keywords: Liming, Enrichment and Translocation Factors, Red Oak (Quercus rubra), ISSR Markers, Northern Ontario

\section{INTRODUCTION}

Northern Ontario especially the Greater Sudbury region is highly known for its nickel, copper and other metal deposits. The mining, roasting and smelting of these elements have caused disastrous effects on the vegetation and overall environment (Amiro and Courtin, 1981; Gratton et al., 2000; Nkongolo et al., 2008; Vandeligt et al., 2011; Narendrula et al., 2012). The region became semi-barren to completely barren and several studies identifiedsulfur dioxide emissions and metal particulates in soil and various plant species to be the main causes of these effects. Concentrations of metal, specifically nickel and copper, have been found to be higher in areas around smelters compared to other regions (Amiro and Courtin, 1981; Narendrula et al., 2012; 2013). The high metal content did increase the levels of soil acidity which affects plant growth. The pHs of these soils ranged from 3.0 to 5.0 with an average of approximately 4.0. Massive restoration projects including Corresponding Author: Anh Tran, Department of Biology, Laurentian University, 935 Ramsey Lake Road, Sudbury, Ontario, P3E-2C6, Canada 
liming of soils and revegetation in the Greater Sudbury Region have been implemented (Lautenbach et al., 1995).

Dolomitic lime which contains calcium and magnesium carbonate was applied to soils from 1980 to 1995 at different locations across Northern Ontario (Lautenbach et al., 1995). Specifically, the role of both calcium and magnesium together is crucial to metal toxicity as they create a competitive exclusion of metal ions from the root-hair's exchange complex, that magnesium and calcium alone is unable to perform and may affect leaf and branch tissue (Winterhalder, 1996). The process of liming aims at neutralizing soil $\mathrm{pH}$ and detoxifying soil from contamination. Soil liming and tree planting have proved to be visually beneficial as the once barren lands now have a prominent increase in vegetation. This is consistent with data from other regions around the world (Rodenkirchen, 1992).

Of the trees planted to date in the Northern Ontario Region of Sudbury, 95\% were conifers and 5\% are hardwood species because of high level of metal tolerance of conifer species (Ryan et al., 1986; Winterhalder, 1995; Narendrula et al., 2013). Red oak (Quercus rubra) is one of the few species found on the drier barren sites and have survived the stresses that caused the loss of the original vegetation (Winterhalder, 1996). A high level of genetic variability is one of the main prerequisites to sustainability and adaptability. Understanding the dynamic of population diversity and variation in the Red oak populations from Northern Ontario Region is essential for the ongoing monitoring of the bio-remediation program and for the assessment of the long term effects of liming on plant populations.

The objectives of the present study were to determine the effects of liming on soil and plant metal accumulation and genetic variation in red oak (Quercus rubra) populations.

\section{MATERIALS AND METHODS}

\subsection{Sampling}

Seven areasin Northern Ontario were selected for the present study. They included four areas consisting of paired limed and unlimed sites (Daisy Lake, Kelly Lake, Wahnapitae and Kingsway) and three reference sites (Capreol, St. Charles and Onaping Falls) (Fig. 1).

The liming was previously performed through the Sudbury's Regional Land Reclamation Program using dolostone. Wahnapitae Hydro Dam site was limed in 1980, Kingsway site was limed in 1981 and Daisy Lake site was limed aerially (Lautenbach et al., 1995). Soil, oak leaf and branch samples were collected from each site. For each area, 10 pedons were sampled, with soil samples being collected from the surface Humus Form (LFH), as well as from the underlying mineral horizons (namely the $\mathrm{Ae}, \mathrm{Bm}, \mathrm{BC}$ and $\mathrm{C}$, if present). Only the top organic layer samples were analyzed in the present study. Soil samples were air dried and stored in sealed plastic bags prior to preparation for chemical analysis. Oak leaves and branches were collected randomly from 20 individual trees and dried for further analysis.

\subsection{Metal Analysis}

Soil $\mathrm{pH}$ was measured in water and a neutral salt solution $\mathrm{pH}\left(0.1 \mathrm{M} \mathrm{CaCl}_{2}\right.$ ) (Carter, 1993). Total metal analysis was performed as described by (Abedin et al., 2012). For the estimation of total metal concentrations, a $0.5 \mathrm{~g}$ soil sample was treated with $10 \mathrm{~mL}$ of $10: 1$ ratio $\mathrm{HF}$ : $\mathrm{HCl}$, heated to $110^{\circ} \mathrm{C}$ for $3.5 \mathrm{~h}$ in open $50 \mathrm{~mL}$ Teflon $^{\mathrm{TM}}$ tube in a programmable digestion block to dry down samples, followed by addition of $7.5 \mathrm{~mL}$ of $\mathrm{HCl}$ and $7.5 \mathrm{~mL}$ of $\mathrm{HNO}_{3}$ and heating to $110^{\circ} \mathrm{C}$ for another $4 \mathrm{~h}$ to dry gently. The samples were then heated to $110^{\circ} \mathrm{C}$ for $1 \mathrm{~h}$ following addition of $0.5 \mathrm{~mL}$ of $\mathrm{HF}, 2 \mathrm{~mL}$ of $\mathrm{HCl}$ and $10 \mathrm{~mL}$ of $\mathrm{HNO}_{3}$ to reduce sample volume to $8-10 \mathrm{~mL}$. On cooling, the samples are made to $50 \mathrm{~mL}$ with ultrapure water for subsequent analysis by plasma spectrometry.

Bio available metals were estimated by extracting 5 $\mathrm{g}$ of soil with $20 \mathrm{~mL}$ of $0.01 \mathrm{M} \mathrm{LiNO}_{3}$ in a $50 \mathrm{~mL}$ centrifuge tubes in a shaker under ambient lighting conditions for $24 \mathrm{~h}$ at $20^{\circ} \mathrm{C}$ (Spiers and Abedin, 2006; Abedin et al., 2012). The $\mathrm{pH}\left(\mathrm{LiNO}_{3}\right)$ of the suspension was measured prior to centrifugation at $3000 \mathrm{rpm}$ for 20 min with filtration of the supernatant through a 0.45 $\mu \mathrm{m}$ filter into a $20 \mathrm{~m} \mathrm{~L}$ polyethylene tube and made to volume with deionized water. The filtrate was preserved at approximately $3^{\circ} \mathrm{C}$ for analysis by ICPMS. The quality control program completed in an ISO 17025 accredited facility (Elliot Lake Research Field Station of Laurentian University) included analysis of duplicates, Certified Reference Materials (CRM's), Internal Reference Materials (IRM's), procedural and calibration blanks, with continuous calibration verification and use of internal standards ( $\mathrm{Sc}, \mathrm{Y}, \mathrm{Bi})$ to correct for any mass bias. All concentrations were calculated in mass/mass dry soil basis. The data obtained for all elements of interest in analyzed CRM soil samples were within $\pm 12 \%$ of the certified level. Metal content in leaves and branches was determined according to the protocol described by (Nkongolo et al., 2008; Abedin et al., 2012). 


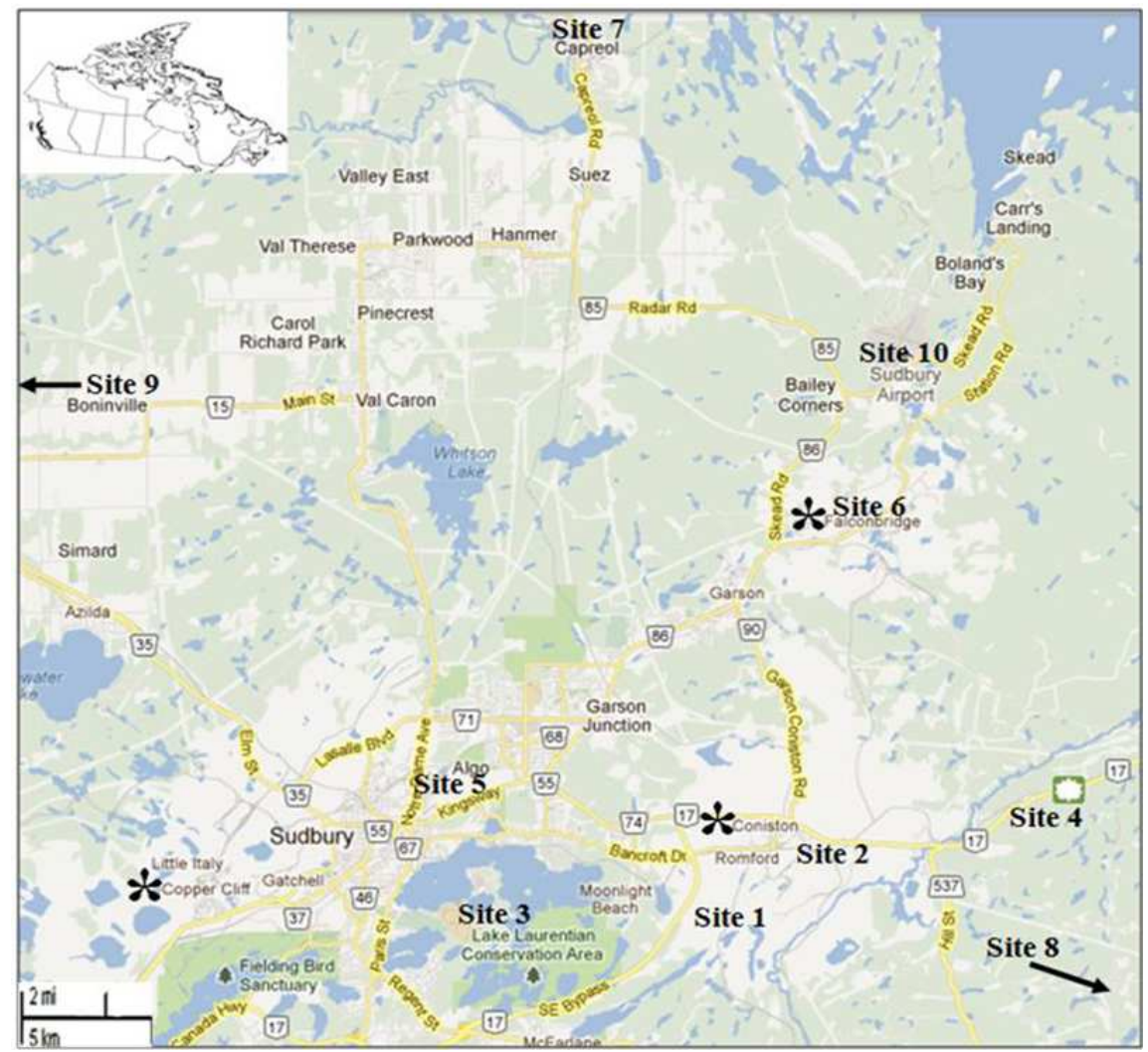

Fig. 1. Location of red oak (Quercus rubra) sampling sites within the greater Sudbury region in Northern Ontario. Site 1: Daisy Lake; Site 2: Wahnapitae Hydro Dam; Site 3: Laurentian; Site 4: Kukagami; Site 5: Kingsway; Site 6: Falconbridge; Site 7:

\subsection{Statistical Analysis}

The data for the metal levels in soil and tissue samples were analyzed using SPSS $7.5^{\mathrm{TM}}$ for Windows, with all data being transformed using a $\log _{10}$ transformation to achieve a normal distribution.

Variance-ratio test was done with an assumption of data normality in the underlying population distributions of the data. ANOVA, followed by Tukey's HSD multiple comparison analysis, were performed to determine significant differences $(\mathrm{p}<0.05)$ among the sites. Data from analysis of samples from limed and no limed areas were compared using the Student-T test.

The Enrichment Factor (EF) and the Translocation Factor (TF) were determined according to the equations described by (Singh et al., 2010).

\subsection{Molecular Analysis}

Fresh Quercus rubra leaf samples were collected from the targeted sites in Northern Ontario based on leaf morphology. Twenty trees representing each targeted population were selected for the study. Leaf samples were wrapped in aluminum foil, immersed in liquid nitrogen and stored at $-20^{\circ} \mathrm{C}$ until DNA extraction.

\subsection{DNA Extraction}

Genomic DNA was extracted from fresh frozen leaf material using the CTAB extraction protocol as described by (Nkongolo, 1999; Mehes et al., 2007). The protocol is a modification of (Doyle and Doyle, 1987) procedure. The modifications included the addition of $1 \%$ Poly Vinyl Pyrrolidone (PVP) and $0.2 \%$ beta mercaptanol to the Cetyl Trimethyl Ammonium Bromide (CTAB) buffer solution, two additional chloroform spins prior to the is opropanol spin and no addition of RNA se. After extraction, DNA was stored in a freezer at $-20^{\circ} \mathrm{C}$.

\subsection{ISSR Analysis}

A total of 15 ISSR primers were pre-screened for polymorphism and reproducibility of these, eight primers 
were identified. These included 178 99A, 178 99B, UBC 841, UBC 825, ISSR 5, 8, 9 and 10. Five of these eight primers (178 98B, UBC 825, ISSR 5, 9 and 10) that produced strong bands were selected for ISSR analysis.

PCR amplification was carried out as described by (Mehes et al., 2007) in a $25 \mu \mathrm{L}$ total volume containing a master mix of $11.4 \mu \mathrm{L}$ distilled water, $2.5 \mu \mathrm{L} \mathrm{MgSO}_{4}$, $2.1 \mu \mathrm{L} 10 \times$ buffer $0.5 \mu \mathrm{L}$ of dNTPs (equal parts dTTP, dATP, dCTP, dGTP), $0.5 \mu \mathrm{L}$ of ISSR primer, a Taqmix of $3.475 \mu \mathrm{L}$ distilled water, $0.4 \mu \mathrm{L} 10 \times$ buffer and 0.125 $\mu \mathrm{L} \mathrm{Taq}$ polymerase (Applied Biosystems) and $4 \mu \mathrm{L}$ standardized DNA. Each primer contained a negative control of master mix and Taqmix without any DNA. All samples were covered with one drop of mineral oil to prevent evaporation and amplified with the Eppendorf Mastercycler gradient the rmocycler. The program was set to a hot start of $5 \mathrm{~min}$ at $95^{\circ} \mathrm{C}$ followed by $2 \mathrm{~min}$ at $85^{\circ} \mathrm{C}$ to which the Taqmix was added. In total, 42 cycles of $1.5 \mathrm{~min}$ at $95^{\circ} \mathrm{C}, 2 \mathrm{~min}$ at $55^{\circ} \mathrm{C}$ and one min of $72^{\circ} \mathrm{C}$ were performed. A final extension of $7 \mathrm{~min}$ at $72^{\circ} \mathrm{C}$ after which samples were removed from the the rmocycler and placed in a freezer set at $\mathrm{s}-20^{\circ} \mathrm{C}$ until further analysis.

Amplified DNA products were separated for analysis on a $2 \%$ agarose gel in $0.5 \times \mathrm{TBE}$ with ethidium bromide. Then, $5 \mu \mathrm{L}$ of $2 \times$ loading buffer were added to the PCR products and $10 \mu \mathrm{L}$ of this solution were loaded into the wells of the gel. The gel was run at $64 \mathrm{~V}$ for $120 \mathrm{~min}$, documented with the Bio-Rad Chemi Doc XRS system and analyzed with Image Lab Software.

The ISSR bands on each gel were scored as either present (1) or absent (0). Popgene software version 1.32 (Yeh and Boyle, 1997) was used to determine percentage of polymorphic loci, observed and effective number of alleles, Nei's gene diversity and Shannon's information index. The genetic distances were calculated using Jaccard's similarity coefficients with Free Tree Program version 1.50. A Neighbour-Joining dendogram was produced from the similarity coefficients. The method starts with a star like tree with no hierarchical structure and in a stepwise fashion finds the two operational taxonomic units that minimize the total branch length at each cycle of clustering. The unrooted tree generated by the Neighbour-Joining method is constructed under the principle of minimum evolution (Saitou and Nei, 1987).

\section{RESULTS}

\subsection{Soil Acidity and Metal Contents}

The $\mathrm{pH}$ values of all the sites were determined for the first top organic layer (Table 1). The $\mathrm{pH}$ in limed areas was higher compared to unlimed sites, ranging from 4.12 to 6.75 . The estimated average levels of total and bio available metal concentrations in the soil samples from limed and unlimed areas are illustrated in Table 2 and 3. The control concentrations always showed the lowest levels for total metals analyzed.

Overall, the total magnesium was the only element measured that was significantly higher in limed compared to unlimed sites (Table 2). Arsenic was lower in limed compared to unlimed areas. Detectable values of metal concentrations which are bio available ranged between $0.07 \mathrm{mg} \mathrm{kg}^{-1}$ for strontium and 169.1 $\mathrm{mg} \mathrm{kg}^{-1}$ for magnesium for limed sites. For unlimed areas, the level of bio-available elements ranged from $0.10 \mathrm{mg} \mathrm{kg}^{-1}$ for as to $129.2 \mathrm{mg} \mathrm{kg}^{-1}$ for $\mathrm{K}$. Bio available Magnesium was as expected higher in limed compared to unlimed areas. Bio available strontium and manganese were higher in unlimed compared to limed sites (Table 3).

\subsection{Total Metal Content in Leaves and Branches of Red Oak}

Table 4 and 5 illustrate the mean total metal concentrations in leaves and branches. The total mean concentrations of cadmium and manganese in leaves were found to be significantly higher in limed compared to unlimed sites. Significant differences were also observed between limed and unlimed sites for iron, lead, magnesium and nitrogen in branches (Table 5).

\subsection{Enrichment and Translocation Factors}

The Enrichment Factor (EF) was calculated for the four elements that revealed a significant difference in concentration between metal contaminated and control sites. For total metals, the EF values were found to be 16.78, 4.98 and 2.94 for arsenic, copper and nickel, respectively. The Translocation Factors (TF) were calculated in contaminated sites from soil to branches. In general, The TFs from soil to branches were low for both total and bio available metals in reference control sites compared to contaminated sites. The TF values were very low for all total metals except for magnesium and phosphorus. The TF of bio available elements from soil to branches were very high ranging from 1.90 to 266.3 for contaminated sites (Table 6). There were higher metal accumulation in leaves compared to branches specifically for aluminum, copper, potassium, magnesium, sulfur and nitrogen (Table 7). 
Table 1. The pH levels of the top organic Layer (LFH) from greater Sudbury region sites

\begin{tabular}{lllr}
\hline Sampling sites & Layer 1type & $\mathrm{pH} \mathrm{H}_{2} \mathrm{O}$ & $\mathrm{pH} \mathrm{CaCl}_{2}$ \\
\hline Daisy Lake & Unlimed & 4.04 & 3.87 \\
& Limed & 4.12 & 4.05 \\
Wahnapitae hydro Dam & Unlimed & 3.82 & 3.56 \\
& Limed & 6.75 & 6.34 \\
Kingsway & Unlimed & 3.87 & 2.35 \\
& Limed & 4.67 & 4.35 \\
Capreol (control) & Unlimed & 3.92 & 3.43 \\
St. Charles (control) & Unlimed & 3.5 & 3.23 \\
Onaping Falls (control) & Unlimed & 3.79 & 3.46 \\
\hline
\end{tabular}

Table 2. Mean concentration of total metals elements in the limed and un imed organic surface Horizons (LFH) of soils from the Sudbury region sites (concentrations are in mg kg-1, dry weight)

\begin{tabular}{|c|c|c|c|c|c|c|c|c|c|c|c|}
\hline \multirow[b]{2}{*}{ Sites } & \multicolumn{11}{|l|}{ Elements $^{\mathrm{a}}$} \\
\hline & As* & $\mathrm{C}$ & $\mathrm{Co}$ & $\mathrm{Cu}$ & K & $\mathrm{P}$ & $\mathrm{Mg}$ & $\mathrm{Mn}$ & $\mathrm{Ni}$ & $\mathrm{Sr}$ & $\mathrm{Zn}$ \\
\hline Limed & $1.46 \pm 1.28$ & $124267 \pm 26533$ & $41 \pm 14$ & $952 \pm 343$ & $7066 \pm 316$ & $571 \pm 93$ & $2309 \pm 672$ & $198 \pm 41$ & $991 \pm 485$ & $58 \pm 12$ & $68 \pm 21$ \\
\hline Unlimed & $18.98 \pm 5.82$ & $136583 \pm 39404$ & $42 \pm 11$ & $1021 \pm 356$ & $8540 \pm 187$ & $600 \pm 37$ & $1548 \pm 194$ & $242 \pm 15$ & $1061 \pm 398$ & $62 \pm 10$ & $73 \pm 16$ \\
\hline
\end{tabular}

${ }^{a}$ Results are expressed as mean values \pm standard errors; *represents significant difference between treatments based on t-test ( $\leq 0.05$ ); Lime and no lime sites: Daisy lake, wahnapitae hydro dam and kingsway

Table 3. Mean concentration of bio available metals elements in the limed and unlimed organic surface Horizons (LFH) of soils from the Sudbury region sites (concentrations are in $\mathrm{mg} \mathrm{kg}^{-1}$, dry weight)

Elements $^{\mathrm{a}}$

\begin{tabular}{|c|c|c|c|c|c|c|c|c|c|c|c|}
\hline Sites & As & $\mathrm{Cd}$ & Co & $\mathrm{Cu}$ & $\mathrm{K}$ & P & $\mathrm{Mg}^{*}$ & $\mathrm{Mn}^{*}$ & $\mathrm{Ni}$ & $\mathrm{Sr}^{*}$ & $\mathrm{Zn}$ \\
\hline & & $<\mathrm{DI}$ & $12 \pm 0$ & 721 & 30 & & 6 & 0 & 1.8 & $.07 \pm 0$ & \\
\hline Inlimed & $0.1 \pm 00$ & $<$ DL- & $0.31 \pm 0$ & $12.04 \pm 3.71$ & $129.22 \pm 24.5$ & $6.05 \pm 2.25$ & $39.78 \pm 5.28$ & $13.95 \pm 3.7$ & $6.85 \pm 2.7$ & $0.33 \pm 0$ & 0.8 \\
\hline
\end{tabular}

${ }^{\mathrm{a}}$ Results are expressed as mean values \pm standard errors; *Represents significant difference between treatments based on $\mathrm{t}$-test ( $\left.\mathrm{p} \geq 0.05\right)$; Limed and no limed sites: Daisy lake, wahnapitae hydro dam and kingsway; $<\mathrm{DL}$ indicates concentrations below detectable level

Table 4. Mean total concentration of metals in leaves of red oak (Quercus rubra) from the Sudbury region sites, concentrations are in $\mathrm{mg} \mathrm{kg}$ 1 , dry weight

Elements $^{\mathrm{a}}$

\begin{tabular}{lllllllllllllllllll} 
Sites & $\mathrm{Al}$ & $\mathrm{As}$ & $\mathrm{C}$ & $\mathrm{Ca}$ & $\mathrm{Cd} *$ & $\mathrm{Co}$ & $\mathrm{Cu}$ & $\mathrm{Fe}$ & $\mathrm{K}$ & $\mathrm{P}$ & $\mathrm{Pb}$ & $\mathrm{Mg}$ & $\mathrm{S}$ & $\mathrm{Mn} *$ & $\mathrm{Ni}$ & $\mathrm{N}$ & $\mathrm{Sr}$ & $\mathrm{Zn}$ \\
\hline Limed & 1385 & 0.25 & 469750 & 6647 & 0.080 & 0.460 & 17.6 & 92.90 & 12435 & 2431 & $<\mathrm{DL}$ & 2367 & 2148 & 677 & 27 & 24182 & 9.40 & 2600 \\
& \pm 111 & \pm 0.3 & \pm 14020 & \pm 560 & \pm 0.05 & \pm 0.46 & \pm 3.8 & \pm 12.5 & \pm 2708 & \pm 521 & - & \pm 619 & \pm 522 & \pm 279 & \pm 6 & \pm 6372 & \pm 3.0 & \pm 3.3 \\
Unlimed & 1401 & 0.97 & 470000 & 7282 & 0.230 & 0.150 & 13.6 & 1010 & 11690 & 2149 & $<\mathrm{DL}$ & 2434 & 2172 & 1195 & 24 & 25541 & 9.60 & 2700 \\
& \pm 103 & \pm 0.7 & \pm 13839 & \pm 567 & \pm 0.04 & \pm 0.15 & \pm 1.9 & \pm 100 & \pm 2076 & \pm 498 & - & \pm 269 & \pm 401 & \pm 237 & \pm 4 & \pm 4451 & \pm 1.5 & \pm 3.3 \\
\hline
\end{tabular}

${ }^{\mathrm{a}}$ Results are expressed as mean values \pm standard errors; *Represents significant difference between treatments based on $\mathrm{t}$-test ( $\left.\mathrm{p} \leq 0.05\right)$; Lime and no lime sites: Daisy lake, wahnapitae hydro dam and kingsway; <DL indicates concentrations below detectable level

Table 5. Mean total concentration of metals in branches of red oak (Quercus rubra) from the Sudbury region sites, concentrations are in mg kg-1, dry weight

\begin{tabular}{|c|c|c|c|c|c|c|c|c|c|c|c|c|c|c|c|c|c|c|}
\hline \multirow[b]{2}{*}{$\underline{\text { Sites }}$} & \multicolumn{18}{|c|}{ Elements $^{\text {a }}$} \\
\hline & $\mathrm{Al}$ & As & $\mathrm{C}$ & $\mathrm{Ca}$ & $\mathrm{Cd}$ & Co & $\mathrm{Cu}$ & $\mathrm{Fe}^{*}$ & $\mathrm{~K}$ & $\mathrm{P}$ & $\mathrm{Pb}^{*}$ & Mg* & $\mathrm{Mn}$ & $\mathrm{S}$ & $\mathrm{Ni}$ & $\mathrm{N}^{*}$ & $\mathrm{Sr}$ & $\mathrm{Zn}$ \\
\hline \multirow[t]{2}{*}{ Limed } & 811 & 0.99 & 490750 & 5457 & 0.29 & 0.82 & 33.5 & 269 & 6630 & 1342 & 3.35 & 1098 & 282 & 962 & 25 & 10430 & 15.5 & 220 \\
\hline & \pm 146 & \pm 0.58 & \pm 5662 & \pm 904 & \pm 0.14 & \pm 0.32 & \pm 14 & \pm 192 & \pm 1833 & \pm 363 & \pm 2.0 & \pm 517 & \pm 126 & \pm 208 & \pm 9 & \pm 2760 & \pm 6.4 & \pm 1.3 \\
\hline \multirow[t]{2}{*}{ Unlimed } & 942 & 0.99 & 497000 & 6451 & 0.56 & 0.52 & 15.2 & 98 & 5655 & 1265 & 0.36 & 888 & 524 & 735 & 19 & 9044 & 17.9 & 1800 \\
\hline & \pm 164 & \pm 0.41 & \pm 3216 & \pm 648 & \pm 0.10 & \pm 0.21 & \pm 3 & \pm 40.6 & \pm 836 & \pm 166 & \pm 0.36 & \pm 91.4 & \pm 153 & \pm 134 & \pm 5 & \pm 1937 & \pm 2.7 & \pm 1.7 \\
\hline
\end{tabular}

${ }^{a}$ Results are expressed as mean values \pm standard errors; *Represents significant difference between treatments based on $\mathrm{t}$-test ( $\left.\mathrm{p} \leq 0.05\right) ;$ Lime and no lime sites: Daisy lake, wahnapitae hydro dam and kingsway 
Table 6.The translocation factors for total and bio available metals from soil to branches in metal-contaminated sites Elements

\begin{tabular}{lllllllllrr} 
Translocation factor & As & Co & Cu & \multicolumn{1}{c}{ K } & \multicolumn{1}{c}{ P } & Mg & Mn & Ni & Sr & Zn \\
\hline Total metal from Soil to branches & 0.01 & 0.02 & 0.04 & 0.89 & 2.69 & 0.62 & 1.32 & 0.05 & 0.38 & 0.35 \\
Bio available metal from soil to branches & 1.90 & 4.82 & 4.14 & 94.20 & 266.32 & 8.45 & 41.08 & 7.51 & 138.46 & 32.2 \\
\hline
\end{tabular}

Table 7. Mean concentration of total metals in leaves and branches of red oak (Quercus rubra) from the Sudbury region sites, concentrations are in mg kg-1, dry weight

Elements $^{\mathrm{a}}$

\begin{tabular}{|c|c|c|c|c|c|c|c|c|c|c|c|c|c|c|c|}
\hline Type & $\mathrm{Al}$ & As & $\mathrm{Ca}$ & $\mathrm{Cd}$ & $\mathrm{Co}$ & $\mathrm{Cu}$ & $\mathrm{Fe}$ & $\mathrm{K} *$ & $\mathrm{P}$ & $\mathrm{Pb} *$ & $\mathrm{Mg}^{*}$ & $\mathrm{Mn}$ & $\mathrm{Ni}$ & $\mathrm{Sr}$ & $\mathrm{Zn}$ \\
\hline \multirow[t]{2}{*}{ Leaves } & 1190 & 0.60 & 6718 & 0.200 & 0.20 & 14.2 & 87.80 & 10967 & 2138 & 0.020 & 2568 & 9320 & 220 & 9.40 & 2700 \\
\hline & \pm 152 & \pm 0.4 & \pm 421 & \pm 0.03 & \pm 0.2 & \pm 1.7 & \pm 10.3 & \pm 1377 & \pm 326 & \pm 0.02 & \pm 295 & \pm 168 & \pm 3.5 & \pm 1.2 & \pm 1.90 \\
\hline \multirow[t]{2}{*}{ Branches } & 7620 & 0.80 & 6587 & 0.500 & 0.50 & 19.7 & 139.1 & 53280 & 1123 & 1.300 & 1071 & 4040 & 190 & 20.3 & 21000 \\
\hline & \pm 131 & \pm 0.3 & \pm 553 & \pm 0.10 & \pm 0.2 & \pm 5.0 & \pm 63.0 & \pm 7460 & \pm 157 & \pm 0.70 & \pm 198 & \pm 970 & \pm 4.1 & \pm 3.2 & \pm 1.20 \\
\hline
\end{tabular}

Table 8. The nucleotide sequences of ISSR primers used to amplify DNA from red oak samples

\begin{tabular}{llll}
\hline ISSR Primer Identification & \multicolumn{2}{c}{ Nucleotide sequence $\left(5^{\prime} \rightarrow 3^{\prime}\right)$} & GC content $(\%)$ fragment size range $(\mathrm{bp})$ \\
\hline $\mathrm{HB} 15$ & $(\mathrm{GTG})_{3} \mathrm{GC}$ & 72 & $270-2200$ \\
HB 13 & $(\mathrm{GAG})_{3} \mathrm{GC}$ & 72 & $170-1360$ \\
ISSR 17898A & $(\mathrm{CA})_{6} \mathrm{AG}$ & 50 & $270-1450$ \\
ISSR 17898B & $(\mathrm{CA})_{6} \mathrm{GT}$ & 50 & $210-1300$ \\
ISSR UBC 841 & $\mathrm{GAAG}(\mathrm{GA})_{6} \mathrm{YC}$ & 50 & $250-1100$ \\
ISSR UBC 829 & $(\mathrm{TG})_{7} \mathrm{C}$ & 53 & $200-4000$ \\
ISSR UBC 827 & $(\mathrm{AC})_{8} \mathrm{G}$ & 60 & $600-1000$ \\
ISSR UBC825 & $(\mathrm{AC})_{8} \mathrm{~T}$ & 53 & $305-1000$ \\
SC ISSR 10 & $(\mathrm{CTT})_{5}(\mathrm{CCT})_{6} \mathrm{CT}$ & 51 & \\
SC ISSR 9 & $(\mathrm{GATC})_{3} \mathrm{GC}$ & 57 & \\
SC ISSR 8 & $(\mathrm{AGAT})_{4} \mathrm{GY}$ & 27 & \\
SC ISSR 7 & $(\mathrm{AGG})_{5} \mathrm{GY}$ & 65 & $310-1500$ \\
SC ISSR 6 & $(\mathrm{TTG})_{5} \mathrm{CB}$ & 35 & \\
SC ISSR 5 & $(\mathrm{ACG})_{4}$ & 67 & \\
SC ISSR 4 & $(\mathrm{CGT})_{4} \mathrm{C}$ & 69 & \\
\hline
\end{tabular}

Table 9. Genetic variability parameters of red oak (Quercus rubra) populations based on ISSR data

\begin{tabular}{|c|c|c|c|c|c|}
\hline Populations (Distances from smelters) & $\mathrm{P}(\%)$ & $\mathrm{Na}$ & $\mathrm{Ne}$ & $\mathrm{h}$ & I \\
\hline Daisy lake limed (<5 km) & 51.77 & 1.52 & 1.21 & 0.13 & 0.20 \\
\hline Daisy lake unlimed (<5 km) & 52.48 & 1.52 & 1.20 & 0.13 & 0.20 \\
\hline Wahnapitae hydro dam limed (<5 km) & 51.77 & 1.52 & 1.20 & 0.13 & 0.21 \\
\hline Wahnapitae hydro dam unlimed ( $<5 \mathrm{~km})$ & 54.61 & 1.55 & 1.21 & 0.13 & 0.21 \\
\hline Kingsway limed (5-15 km) & 54.61 & 1.55 & 1.18 & 0.12 & 0.19 \\
\hline Kingsway unlimed (5-15 km) & 58.87 & 1.59 & 1.22 & 0.14 & 0.23 \\
\hline St. Charles (control>15 km) & 43.97 & 1.44 & 1.21 & 0.13 & 0.20 \\
\hline Onaping falls (control>15 km) & 51.06 & 1.51 & 1.22 & 0.13 & 0.21 \\
\hline Mean & 46.01 & 1.54 & 1.22 & 0.14 & 0.22 \\
\hline
\end{tabular}

Genetic diversity descriptive statistics P: Percentage of polymorphic loci; Na: Observed number of alleles; Ne: Expected number of alleles; h: Gene diversity (Nei, 1973); I: shannon's information index

\subsection{ISSR Analysis of Red Oak Populations from Targeted Sites}

\subsubsection{Genetic Diversity}

Table 8 describes the main characteristics of ISSR primers screened in the present study. Figure 2 depicts amplified products of genomic DNA from red oak maple samples using the ISSR primer 5. The percentage of polymorphic loci (\%), the observed Number of alleles $(\mathrm{Na})$, the effective Number of alleles (Ne), Nei's gene diversity (h) and Shannon's Information index (I) were estimated and they are described in Table 9. 


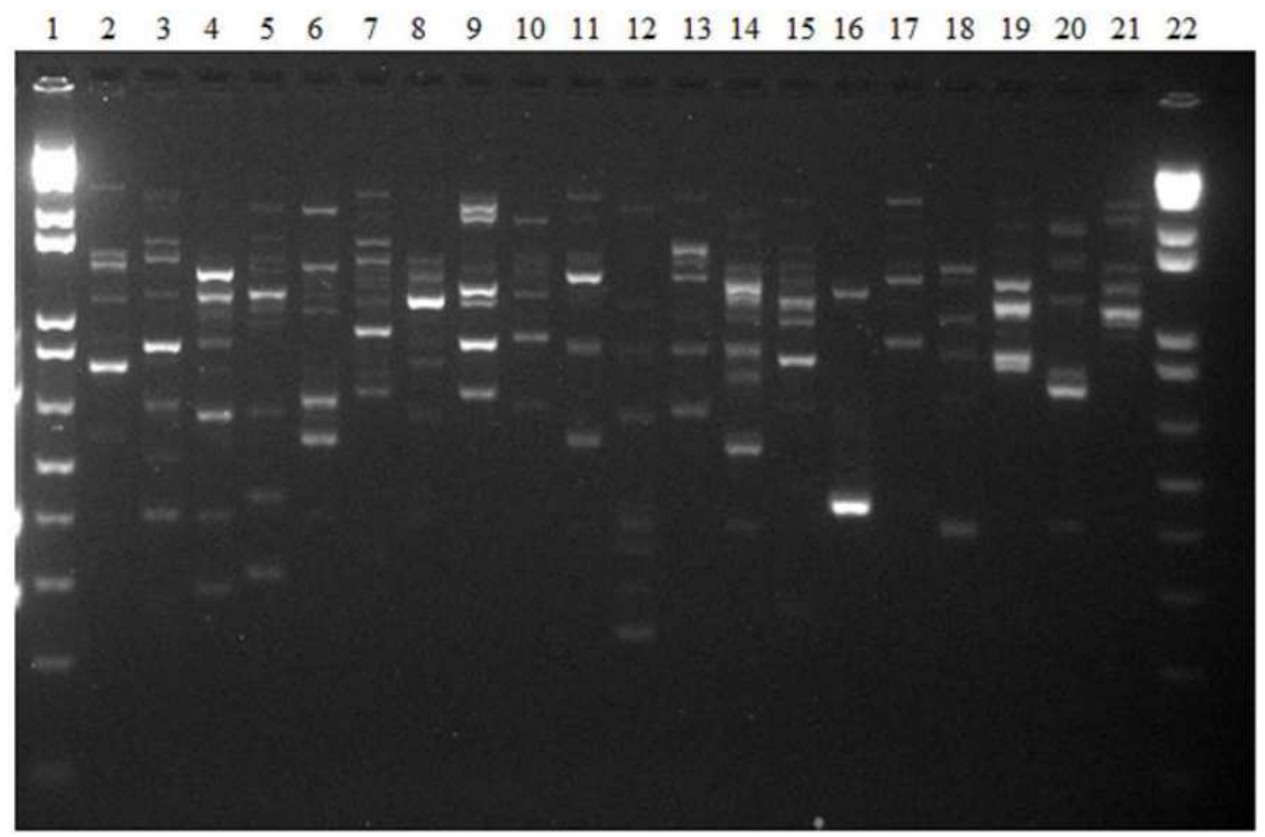

Fig. 2. ISSR amplification of red oak samples with primer ISSR 5. Lanes 1 and 22 contain $1 \mathrm{~kb}+$ ladder; Lanes 2-21 contain red oak

The mean values for $\mathrm{Na}, \mathrm{Ne}, \mathrm{h}$ and $\mathrm{I}$ were 1.54 , $1.22,0.14$ and 0.22 . The level of inter-population polymorphism was $97.87 \%$. The total gene diversity (HT) and the mean gene diversity between populations (HS) were 0.21 and 0.14 , respectively. The population differentiation (GST) value was 0.34 and the estimated gene flow $(\mathrm{Nm})$ was 0.98 . The levels of polymorphism per primer were $61,73,66,56$ and $48 \%$ for $17898 \mathrm{~B}$, UBC 825, ISSR 10, ISSR 9 and ISSR 5 primers, respectively.

The levels of genetic variation in all populations were moderate to high. In fact the percentage of polymorphic loci varied between $43.97 \%$ (St. Charles) and $64.54 \%$ (Capreol). The observed number of alleles ranged from 1.44 (St. Charles) to 1.65 (Capreol) with a mean of 1.54. The expected number of alleles ranged from 1.18 (Kingsway, limed) to 1.28 (Capreol) with a mean of 1.22. Nei's gene diversity, h, ranged from 0.12 (Kingsway, limed) to 0.17 (Capreol) with a mean of 0.14. Shannon's information index revealed a range between 0.19 (Kingsway, limed) and 0.27 (Capreol) with a mean of 0.22 . The mean polymorphic indices were determined for limed and unlimed area. No significant differences for the level of polymorphism was observed between the two groups. The mean levels of polymorphism were 53 and $55 \%$ for limed and unlimed populations, respectively.

\section{DISCUSSION}

\subsection{Long Term Effects of Liming on Soil Toxicity}

Several studies have been conducted on the fitness and viability of the introduced plant species (Backor and Fahselt, 2004; Vandeligt et al., 2011; Narendrula et al., 2013). The present study is the first that assesses the sustainability of a hardwood species in stressed areas in Northern Ontario.

Monitoring the long term consequences of metal contamination as well as the results of land remediation is important to determine ecological stability. The levels of total metal concentrations in the organic-rich upper soil Horizon (LFH) were consistent with previous studies and confirm that the metal particulates found in soil are dominantly due to an airborne cause (Amiro and Courtin, 1981; Gratton et al., 2000; Nkongolo et al., 2008; Vandeligt et al., 2011; Narendrula et al., 2012; 2013).

The bio available metal level in soil analyzed in the present study was determined to be a critical aspect of phytoxicity. Although total amounts of metal content in soil of certain sites were high, the percentage of bio available metal relative to total metal was much lower. This indicates that the metal amount readily available to 
plants is small and therefore the toxicity of such contaminated soils might be minimal.

The most profound effect of liming is the high level of $\mathrm{pH}$ in limed sites compared to unlimed areas. Soil $\mathrm{pH}$ is an important factor in regulating metal and nutrient content. If it is too low, the availability of nutrients to plants may be disrupted as seen in the barren lands of the Sudbury region (Rodenkirchen, 1992; Winterhalder, 1996). Increasing soil $\mathrm{pH}$ will also affect the rate of organic matter mineralization. The $\mathrm{pH}$ values found in this present study shows that the liming of soils 20 to 30 years ago continues to produce long term advantages. High $\mathrm{pH}$ values are also reflected on the metal content as there were significantly lower bio available concentrations of aluminum, iron and strontium in limed areas. It should be pointed that although smelters are still currently in use, $\mathrm{pH}$ values were not as low as values recorded prior to liming. For example, extremes $\mathrm{pH}$ values were once recorded to have been slightly over 2 (Winterhalder, 1996). The current improvement in soil toxicity even in unlimed sites compared to past records are likely the results of the abatement policies.

Overall, the application of dolomitic limes over 20 years ago continue to have an impact on total concentration of metals of interest for Northern Ontario that include total $\mathrm{Cu}, \mathrm{Ni}, \mathrm{Co}, \mathrm{Zn}$ and $\mathrm{Cd}$ The levels of these metals in limed sites were lower than unlimed areas. Total arsenic concentrations were significantly higher in limed areas compared to reference unlimed areas. The amount of bio available strontium was significantly lower in limed sites compared to unlimed sites. A measurable decrease in bio available amounts of $\mathrm{Co}, \mathrm{Cu}, \mathrm{K}, \mathrm{Mg}, \mathrm{Ni}$ and $\mathrm{Zn}$ was observed in limed compared to unlimed sites. The amounts of bio available $\mathrm{Ca}$ and $\mathrm{Mg}$ is measurably higher in limed areas which reflects the addition of calcitic and dolomitic lime. The neutralizing power of the limestone was expected to halt eventually leading to a deterioration of the plant community. However, as the present study illustrated, this is not the case. The lasting effect of liming for over 30 years may be the result of soil detoxification requiring roots to penetrate further into the soil and cycling calcium and magnesium from lower horizons to the surface layer. This phenomenon is referred to as a cation pump (Jordan, 1987).

Total cadmium and manganese were significantly different in leaf samples from limed compared to unlimed areas. Iron, lead, magnesium and nitrogen were significantly different in branch samples of limed compared to unlimed areas.

\subsection{Enrichment and Translocation Factors}

The Enrichment Factor (EF) was calculated to establish the degree of soil contamination and heavy metal accumulation. It is the ratio between the concentration of metals in contaminated soil and the concentration of metals in reference sites. Values greater than 1 indicate environmental pollution (Singh et al., 2010). The EF for the present study was determined for the three elements which contained a significant difference between contaminated and reference sites. These elements included $\mathrm{As}, \mathrm{Cu}$ and $\mathrm{Ni}$. Their respective EF values were 16.78, 4.98 and 2.94. EF for arsenic, copper and nickel are far above the value of contamination resulting in high availability and distribution of metals in soil. The high EF values of copper and nickel are attributed to the mining and smelting activities which occur in Sudbury. These values may be an indication that there may ultimately be an increase in metal accumulation in plants located on reference sites (Gupta et al., 2008).

Translocation of metals from soil or roots to above ground tissues is a crucial physiological process in an effective utilization of plant to remediate polluted sites (Zacchini et al., 2009; Galfati et al., 2011; Majid et al., 2012). In the present study, the Translocation Factor (TF) was calculated as the ratio of the concentration of total metal in plant tissues and the concentration of total and bio available metals in corresponding soil. It is used to determine relative translocation of metals from the soil to branches. The TF for total metals were relatively low for the majority of elements. But the TF values based on bio available metals in soils were high for both contaminated and uncontaminated sites.

The accumulation of metals in leaves was greater than in branches indicating a higher mobility of elements within the plant tissues itself. Singh et al. (2010) estimated the translocation factor based on total metal in soil only. This approach is not accurate because it underestimates the translocation by considering a large proportion of total metals that are in forms that are not readily available to plants. The assessment of translocation factors based on total metals in roots or bio available elements in soil such as described in the present study should provide reliable information on metal movement from soil to aerial plant tissues.

The analysis of plant tissues was important in determining the level of metal uptake and the mobility of elements from the soil. There was also a significant difference in total potassium, lead, magnesium, manganese, sulfur and nitrogen between leaves and 
branches. The levels of these metals were higher in leaves compared to branches with the exception of lead.

The amount of total metal concentrations found in the tissues is much lower than the total amount in soil, but significantly higher than the bio available metals in soil. This indicates that Red oak plants are able to accumulate metals in their tissues. This is consistent with (Leavitt et al., 1979) who reported accumulations of $\mathrm{Ag}, \mathrm{Cd}, \mathrm{Cu}$ and $\mathrm{Zn}$ metals in red oaks tissues and exclusion of $\mathrm{Pb}$ in leaves and twig. Based on the result of the present study, red oak might play a role in phytoextraction of metals from the Sudbury soils. Considering that this species represents up to $10 \%$ of all tree species in the targeted sites, it can contribute to phytostabilisation (a component of phytoremediation) of restored forests, since it is able to grow and survive on heavily contaminated soil.

\subsection{ISSR Analysis}

Determining plant sustainability is a critical process in monitoring land restoration. A decline in genetic variability may stunt the species gene pool and therefore decreases its chances of survival in environmental stresses. In the present study, northern red oak samples from 13 populations were analyzed using ISSR markers to determine the level of genetic variability.

Several molecular markers have been used to determine genetic variability in different taxa. The Inter-Simple Sequence Repeat (ISSR) system is a very useful and efficient tool used in assessing genetic variation of plant populations. It combines the advantages of SSRs and Amplified Fragment Length Polymorphism (AFLP) to the universality of Random Polymorphic DNA (RAPD) (Reddy et al., 2002).

In the present study, the level of polymorphic loci ranged from 43.97 to $64.54 \%$. This indicates a moderateto high levelsof genetic variability. No significant differences in polymorphisms were observed between populations fromlimed and unlimed areas. This is consistent with previous data on conifer species (Vandeligt et al., 2011; Dobrzeniecka et al., 2011; Narendrula et al., 2013). This lack of significant differences for genetic variability among populations suggests that the level of metals in plant tissue is too low to play an important role in genotypic selection that can affect the allelic frequencies within the targeted population.

Nei's gene diversity (h) was also determined. The mean value of $h$ for red oak populations analyzed was low (0.14) indicating that allelic frequencies were quite similar for the targeted red oak populations. Shannon's Information index (I) values (mean of 0.22) indicates an uneven distribution of alleles in the populations.

\section{CONCLUSION}

The results of the present study revealed that the highest concentrations of metal and nutrients were observed in the topmost organic layer, LFH. The pH levels of limed areas were higher than unlimed sites, an indication of the prolonged beneficial effect of liming 20 to 30 years ago on soil toxicity. The proportion of total metals that was bio available and readily available to plants was very small. The concentrations of metal in plant tissue were found to be higher than the bio available metals in soil. The Enrichment Factor (EF) varied between 2.94 and 16.78 indicating environmental pollution. The Translocation Factors (TF) from soil to branches were low for most total elements. But the TF values for bio available metals from soil to branches were high. There was more metal accumulation in leaves compared to branches. The ISSR analysis revealed that the genetic variability within red oak populations in the Greater Sudbury Region (GSR) was moderate to high ranging from 43.97-64.54\%.

\subsection{Future Research Directions, Limitations and Implication}

Knowledge of coping mechanisms of red oak to soil metal accumulation is essential to our understanding of the metal tolerance strategy for different hardwood species. The low levels of TF suggest that red oak is likely not the species of choice for bioremediation.

\section{ACKNOWLEDGEMENT}

Thanks to Paul Michael for formatting and editing. We express our appreciation to the Natural Sciences and Engineering Research Council of Canada (NSERC), Vale Limited and Glencore Limited (formely Xstrata Limited) for their financial support.

\section{REFERENCES}

Abedin, J., P. Beckett and G. Spiers, 2012. An evaluation of extractants for assessment of metal phytoavailability to guide reclamation practices in acidic soilscapes in northern regions. Canad. J. Soil Sci., 92: 253-268. DOI: 10.4141/cjss2010-061. 
Jordan, W.R., 1987. Restored Forests and the Identification of Critical Factors in Species-Site Interactions. In: Restoration Ecology: A Synthetic Approach to Ecological Research, Jordan, W.R., M.E. Gilpin and J.D. Aber (Eds.)., Cambridge University Press, Cambridge, U.K., ISBN-10: 9780521337281, pp: 342.

Amiro, B.D. and G.M. Courtin, 1981. Patterns of vegetation in the vicinity of an industrially disturbed ecosystem, Sudbury, Ontario. Canadian J. Botany, 59: 1623-1639. DOI: 10.1139/b81-221

Backor, M. and D. Fahselt, 2004. Physiological attributes of the lichen Cladonia pleurota in heavy metalrich and control sites near Sudbury (Ont., Canada). Environ. Exp.. Botany, 52: 149-159. DOI: 10.1016/j.envexpbot.2004.01.014

Carter, M.R., 1993. Soil Sampling and Methods of Analysis. 2nd Edn., Lewis, Boca Raton, FL, ISBN10: 0873718615, pp: 823.

Dobrzeniecka, S., K.K. Nkongolo, P. Michael, M. MehesSmith and P. Beckett et al., 2011. Genetic analysis of black spruce (Picea mariana) populations from dry and wet areas of a metal-contaminated region in Ontario (Canada). Water Air Soil Pollut., 215: 117-125. DOI: 10.1007/s11270-010-0463-4

Doyle, J.J. and J.L. Doyle, 1987. A rapid DNA isolation procedure for small quantities of fresh leaf tissue. Phytochemical Bull., 19: 11-15.

Galfati, I., E. Bilal, A.B. Sassi, H. Abdallah and A. Zaier et al., 2011. Accumulation of heavy metals in native plants growing near the phosphate treatment industry, Tunisia. Carpathian J. Earth Environ. Sci., 6: 85-100.

Gratton, W.S., K.K. Nkongolo and G.A. Spiers, 2000. Heavy metal accumulation in soil and jack pine (Pinus banksiana) needles in Sudbury, Ontario, Canada. Bull. Environ. Contaminat. Toxicol., 64: 550-557. DOI: 10.1007/s001280000038

Gupta, S., S. Nayek, R.N. Saha and S. Satpati, 2008. Assessment of heavy metal accumulation in macrophyte, agricultural soil and crop plants adjacent to discharge zone of sponge iron factory. Environ. Geol., 55: 731-739. DOI: 10.1007/s00254-007-1025-y

Lautenbach, W., J. Miller, P. Beckett, J. Negusanti and K. Winterhalder et al., 1995. Municipal Land Restoration Program: The Regreening Process. In: Restoration and Recovery of an Industrial Region, Gunn, J. (Ed.)., Springer, New York, ISBN-10: 9781-4612- 7568-8, pp: 109-122.

Leavitt, S.W., R.D. Dueser and H.G. Goodell, 1979. Plant regulation of essential and non-essential heavy metals. J. Applied Ecol., 16: 203-212.
Majid, N.M., M.M. Islam, R.A. Rauf, P. Ahmadpour and A. Abdu et al., 2012. Assessment of heavy metal uptake and translocation in Dyera costulata for phytoremediation of cadmium contaminated soil. Acta Agric. Scandinavica Sec. B-Soil Plant Sci., 62: 245-250. DOI: 10.1080/09064710.2011.603740

Mehes, M.S., K.K. Nkongolo and P. Michael, 2007. Genetic analysis of Pinus strobus and Pinus monticola populations from Canada using ISSR and RAPD markers: Development of genome-specific SCAR markers. Plant Systemat. Evolut., 267: 47-63. DOI: $10.1007 / \mathrm{s} 00606-007-0534-1$

Narendrula, R., K. Nkongolo and P. Beckett, 2012. Comparative soil metal analyses in Sudbury (Ontario, Canada) and Lubumbashi (Katanga, DRCongo). Bull. Environ. Contaminat. Toxicol., 88: 187-192.

Narendrula, R., K.K. Nkongolo, P. Beckett and G. Spiers, 2013. Total and bioavailable metals in two contrasting mining regions (Sudbury in Canada and Lubumbashi in DR-Congo): Relation to genetic variation in plant populations. Chem. Ecol., 29: 111127. DOI: $10.1080 / 02757540.2012 .696617$

Nkongolo, K.K., 1999. RAPD and cytological analyses of Picea spp. from different provenances: Genomic relationships among Taxa. Hereditas, 130: 137-144. DOI: 10.1111/j.1601-5223.1999.00137.x

Nkongolo, K.K., A. Vaillancourt, S. Dobrzeniecka, M. Mehes and P. Beckett, 2008. Metal content in soil and black spruce (Picea mariana) trees in the Sudbury region (Ontario, Canada): Low concentration of arsenic, cadmium and nickel detected near smelter sources. Bull. Environ. Contaminat. Toxicol., 80: 107-111. DOI: 10.1007/s00128-007-9325-1

Reddy, M.P., N. Sarla and E.A. Siddiq, 2002. Inter Simple Sequence Repeat (ISSR) polymorphism and its application in plant breeding. Euphytica, 128: 917. DOI: 10.1023/A:1020691618797

Rodenkirchen, H., 1992. Effects of acidic precipitation, fertilization and liming on the ground vegetation in coniferous forests of southern Germany. Water, Air Soil Poll., 61: 279-294. DOI: 10.1007/BF00482611

Ryan, P.J., S.P. Gessel and R.J. Zasoski, 1986. Acid tolerance of Pacific Northwest conifers in solution culture. Plant Soil, 96: 259-272. DOI: 10.1007/BF02374769

Saitou, N. and M. Nei, 1987. The neighbor-joining method: A new method for reconstructing phylogenetic trees. Molecular Biol. Evolut., 4: 406425. PMID: 3447015 
Singh, R., D. Singh, N. Kumar, S. Bhargava and S. Barman, 2010. Accumulation and translocation of heavy metals in soil and plants from fly ash contaminated area. J. Environ. Biol., 31: 421-430. PMID: 21186714

Spiers, G. and J. Abedin, 2006. Metal bioavailability in smelter-impacted land systems. Proceedings of the 31st Annual Meeting and Conference of the Canadian Land Reclamation Association, (LRA' 06), pp: 1-17.

Vandeligt, K.K., K.K. Nkongolo, M. Mehes and P. Beckett, 2011. Genetic analysis of Pinus banksiana and Pinus resinosa populations from stressed sites contaminated with metals in Northern Ontario (Canada). Chem. Ecol., 27: 369-380. DOI: 10.1080/02757540.2011.561790

Winterhalder, K., 1995. Early History of Human Activities in Enviromental Restoration and Recovery of an Industrial Region. In: Restoration and Recovery of an Industrial Region: Progress in Restoring the Smelter-Damaged Landscape Near Subdury, Canada, Gunn, J. (Ed.)., Springer-Verlag New York, Inc., USA, ISBN-10: 0-387-94430-3, pp: 17-31.
Winterhalder, K., 1996. Environmental degradation and rehabilitation of the landscape around Sudbury, a major mining and smelting area. Environ. Rev., 4: 185-224. DOI: 10.1139/a96-011

Yeh, F.C. and T.J.B. Boyle, 1997. Population genetic analysis of co-dominant and dominant markers and quantitative traits. Belgian J. Botany, 129: 157-157.

Zacchini, M., F. Pietrini, G.S. Mugnozza, V. Iori, L. Pietrosanti et al., 2009. Metal tolerance, accumulation and translocation in poplar and willow clones treated with cadmium in hydroponics. Water, Air, Soil Poll., 197: 23-34. DOI: $10.1007 / \mathrm{s} 11270-008-9788-7$ 